\title{
Seroprevalence and associated factors of viral agents of the bovine respiratory disease complex in buffaloes of Colombia
}

\author{
Misael Enrique Oviedo Pastrana ${ }^{1^{*}}$ (๑) Erly Carrascal-Triana ${ }^{1} \oplus$ Matiluz Doria $\operatorname{Ramos}^{1} \oplus$ \\ Diego Ortiz Ortega ${ }^{2}$ (D)
}

${ }^{1}$ Corporación Colombiana de Investigación Agropecuaria, Agrosavia, Centro de Investigación Turipaná, Cereté, Córdoba, Colombia. E-mail: moviedo@agrosavia.co."Corresponding author.

${ }^{2}$ Corporación Colombiana de Investigación Agropecuaria, Agrosavia, Centro de Investigación Tibaitatá, Mosquera, Cundinamarca, Colombia.

ABSTRACT: The bovine respiratory disease complex causes sizable losses for livestock producers. Its presentation involves the interaction among multiple viral and bacterial pathogens. Viral agents include: bovine viral diarrhea virus (BVDV), bovine alphaherpesvirus 1 (BoHV-1), bovine parainfluenza virus (bPI3v) and bovine respiratory syncytial virus (BRSV); so far, these viruses have been little studied in the buffalo population. This study is aimed to assess the presence of these viruses in buffalo populations of the department of Córdoba, Colombia. A transversal study was conducted upon assessment of 37 farms and 861 buffaloes. Seroprevalence in animals were as follows: $21.7 \%$ (BVDV), $51.5 \%(B o H V-1), 73.6 \%(b P I 3 v)$ and $58.9 \%$ (BSRV), while seroprevalence in farms stood at: $94.6 \%(B V D V), 100 \%(B o H V-1), 100 \%(b P I 3 v)$ and $100 \%(B S R V)$. Conversely, the multiple seropositivity in buffaloes or past coinfection of viral agents amounted to $23.3 \%$ for a single virus, $31.8 \%$ for two viruses, $29.4 \%$ for three viruses and $7.1 \%$ for four viruses; only $8.4 \%$ of buffaloes were seronegative for four viruses. This is the first regional epidemiological study in the buffalo populations of Colombia and the results showed viral circulation and multiple seropositivity in animals; in addition, the high prevalence found pose a concerning epidemiological threat.

Key words: epidemiology, viral infection, serology, respiratory disease, buffalo.

Soroprevalência e fatores associados aos agentes virais do complexo respiratório bovino em búfalos da Colômbia

RESUMO: O Complexo de Doenças Respiratórias Bovinas causa perdas significativas aos produtores de gado. Sua apresentação envolve a interação entre múltiplos patógenos virais e bacterianos, dentre os agentes virais estão: vírus da diarreia viral bovina (BVDV), alphaherpesvírus bovino tipo 1 (BoHV-1), vírus da parainfluenza bovina 3 (bPI3v) e vírus sincicial respiratório bovino (BRSV); esses vírus têm sido pouco estudados em populações de búfalos. O objetivo deste estudo foi avaliar a presença destes vírus em populações de búfalos do departamento de Córdoba, Colômbia. Foi realizado um estudo transversal, avaliando 37 fazendas e 861 bubalinos. As soroprevalências em animais foram: $21.7 \%(\mathrm{BVDV}), 51.5 \%$ (BoHV-1), $73.6 \%$ (bPI3v) e 58.9\% (BSRV) e as soroprevalencias em fazendas foram: $94.6 \%$ (BVDV), $100 \%$ (BoHV-1), 100\% (bPI3v) e 100\% (BSRV). Por outro lado, a soropositividade múltipla em búfalos ou infectividades acontecidas dos agentes virais foi de $23.3 \%$ para um único vírus, $31.8 \%$ para dois vírus, $29.4 \%$ para três vírus e $7.1 \%$ para os quatro vírus; apenas $8.4 \%$ dos búfalos foram soronegativos para os quatro vírus. Este é o primeiro estudo epidemiológico regional em populações de búfalos da Colômbia, os resultados evidenciam a circulação viral e múltiplas infecções em animais; além disso, as altas prevalências encontradas apresentam um cenário epidemiológico preocupante.

Palavras-chave: epidemiologia, infecção viral, sorologia, doença respiratória, búfalo.

\section{INTRODUCTION}

In Colombia, the buffalo population is growing and consolidating rapidly; with the department of Córdoba being the largest producer, gathering $25.4 \%$ (90,760 buffaloes) of the national population, which reached 356,908 animals in 2019 (ICA, 2020). However, infectious agents affect production, where no pathogens involved and epidemiological indicators are clearly identified; a situation that makes it difficult to direct decisionmaking in disease prevention and control. Pathogens that could be generating important economic losses include the viral agents of bovine respiratory disease complex (BRDC).

BRDC is caused by exposure to multiple factors, including environmental stressors (climatic and animal handling procedures), intrinsic factors (age, productive status, and immune response), and the interaction among multiple viral and bacterial 
pathogens (GERSHWIN et al., 2015; GRISSETT et al., 2015). Bacterial agents include Mannheimia haemolytica, Pasteurella multocida, Histophilus somni, Mycoplasma bovis, and Trueperella pyogenes; viral agents include bovine parainfluenza virus (bPI3v), bovine respiratory syncytial virus (BRSV), bovine viral diarrhea virus (BVDV) and bovine alphaherpesvírus 1 (BoHV-1) associated with infectious bovine rhinotracheitis (IBR). Adenovirus, coronavirus, enterovirus, reovirus and influenza D virus have also been reported as viral agents related to bovine respiratory disease (MCGILL \& SACCO, 2020).

The prevalence of BRDC can be high in livestock production systems and is an important cause of morbidity, mortality and economic loss (GERSHWIN et al., 2015; CIRONE et al., 2019). Significant prevalence of BVDV, BoHV-1, bPI3v and BRSV has been reported in cattle in the department of Córdoba (DORIA-RAMOS et al., 2020; BETANCUR et al., 2011; BETANCUR et al., 2010; BETANCUR et al., 2007; BETANCUR et al., 2006). However, these pathogens and their epidemiological indicators have not been identified in buffalo populations. Moreover, the epidemiological role is not clear due to the development of buffalo production in Colombia. This is the first study to present the seroprevalence, combined seropositivity and epidemiological patterns of the main viral agents commonly associated with BRDC in the most important buffalo-producing department of Colombia.

\section{MATERIALS AND METHODS}

\section{Study area}

The study was carried out in the department of Córdoba, in the Caribbean Region of Colombia, an area with high livestock potential under a characteristic lowland tropical ecosystem that is politically divided into 30 municipalities (Figure 1). On average, this department has a relative humidity of $82 \%$, a temperature of $28{ }^{\circ} \mathrm{C}$, an altitude of 30 $\mathrm{m}$ above sea level and $1,400 \mathrm{~mm}$ of precipitation. During the year, there is a dry season (December April) and a rainy season (May - November).

\section{Type of study, population and sample}

A cross-sectional study was conducted in the first semester 2019 in water buffalo (Bubalus bubalis) population of Córdoba, Colombia. The existing buffalo population in the 13 municipalities studied, corresponding to 84,654 animals (ICA, 2020) was used to calculate the sample size (DOHOO et al., 2009). An expected prevalence of $50 \%$, an accepted error of $3.32 \%$ and a confidence level of $95 \%$ were assumed. The sample size was 861 animals that were selected from 37 farms by simple random sampling (Figure 1).

\section{Sampling, processing and diagnosis}

Blood samples were collected from the coccygeal vein using Vacutainer tubes without anticoagulant, the tubes were duly labeled and transported under refrigeration to the laboratory where serum separation was performed at $2000 \mathrm{rpm}$ for 10 minutes. The aliquots were distributed in 1.5 $\mathrm{ml}$ vials and kept at $-20^{\circ} \mathrm{C}$ for subsequent diagnosis in the laboratory of the AGROSAVIA's Tibaitatá Research Center. The enzyme-linked immunosorbent assay (ELISA) was used for serological diagnosis, the Blocking ELISA technique was used for BVDV and BoHV-1 (INgezim PESTIVIRUS Compac and INgezim IBR Compac 2.0, respectively), the Indirect ELISA sa was used for bPI3v (Monoscreen AbELISA BPI3/indirect), and the Competitive ELISA was used for BRSV (INgezim BRSV Compac). The samples were considered as positive when their optical density (OD) value was equal to or lower than the positive cut off and was considered as negative when their OD value was equal to or higher than the negative cut off.

\section{Data analysis}

A descriptive analysis of the data was realized, frequencies and summary statistics were obtained. Seroprevalence was determined in the buffalo population and at the farm level, however, was considered the level of imperfection of each test and was determined the true prevalence $(T P)$ or the actual level of disease (or exposure) that is present in the population of buffaloes. The $T P$ of viruses studied in a population was estimated by $\mathrm{DOHOO}$ et al. 2009:

$$
T P=\frac{A P-(1-S p)}{1-[(1-S p)+(1-S e)]}=\frac{A P+S p-1}{S e+S p-1}
$$

Where, $A P$ is the apparent prevalence or the proportion of the individuals studied who were positive to test; $S e$ is the sensitivity and $S p$ is the specificity of the test.

With the prevalence in the 37 farms studied, two categories were established (high and low prevalence) using the upper limit of the average confidence interval as a cut-off point. Then, relationships were established with the variables: farm size, rotational grazing, use of silage, veterinary assistance, presence of cattle, and purchase of animals. Similarly, univariate analysis was used to 


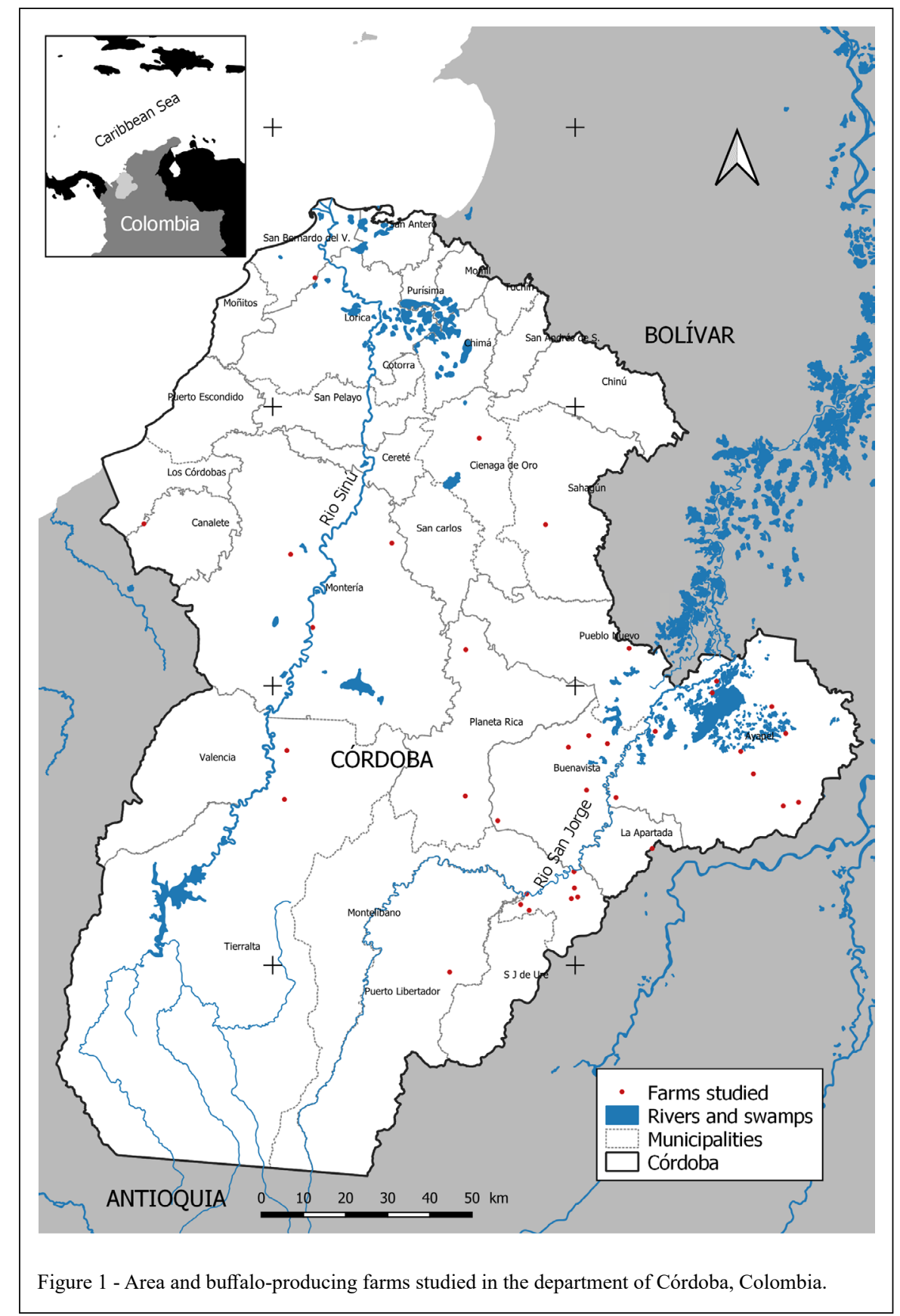

establish comparisons between the seropositivity of each animal (Pos/Neg) and the variables of age, sex, geographic region, and combined seropositivity to the viral agents. Using Chi-square test (significance level up to $20 \%$ ) were pre-selected the variables incorporated in the multivariate logistic regression models for the infectious agents. EpiInfo ${ }^{\circledR}$ software, version 7.2.3.1, was used.

\section{RESULTS}

The studied municipalities concentrate $93.3 \%$ of the buffalo population and $79.0 \%$ of the breeding farms in the department. The buffaloes belonged to the Murrah breed, $75.4 \%$ were females and $24.6 \%$ males; the average age was 3.9 years $(95 \%$ CI, $3.7-4.1)$. The studied farms ranged from 20 to 
4300 ha, with an average of 908 ha (95\% CI, 534 to 1283 ), $64 \%$ had rotational grazing, 36\% used silage, and $66 \%$ had buffalo containment chutes; $64 \%$ had veterinary assistance, but focused on the reproductive management of the animals; $44 \%$ purchased buffalo from other farms, and 53\% had combined buffalo and cattle operations. Of the farms in the study, $36 \%$ had had respiratory clinical histories, and $69 \%$ had had reproductive clinical histories. All the farms had established vaccination plans against officially controlled diseases (foot-and-mouth disease, brucellosis and rabies) and against clostridial diseases. No farms had established vaccination plans against the viral agents studied in this research. No relationship was found between farms with high prevalence and the above variables.

Prevalence in farms and animals for BVDV, BoHV-1, bPI3v and BRSV is shown in table 1 , the results of apparent and true prevalence at the local or municipal level and at the regional or departmental level are shown in the table.

For BVDV, an apparent prevalence (AP) of $22.6 \%$ and a true prevalence (TP) of $21.7 \%$ were found (blocking ELISA, sensitivity 90\%; specificity 96\%); the average animal prevalence in the 37 farms was $21.9 \%$ (95\% CI, 16.2 - 27.6), 10 farms were above the average with values between $33.3 \%$ and $83.3 \%$. The highest prevalences were found in the municipalities of Tierralta (28.6\%), Buenavista (27.9\%), Planeta Rica (27.3\%), Ayapel (26.5\%) and Montelibano $(23.2 \%)$. At the farm level, the prevalence was $94.6 \%$; only two out of the 37 visited farms were negative. The projection of BVDV-affected animals identified 18,356 seropositive buffaloes in 250 farms in the region. In the 13 municipalities studied, only Pueblo Nuevo showed no evidence of viral circulation.

For BoHV-1, AP $=50.4 \%$ and $\mathrm{TP}=$ $51.5 \%$ (blocking ELISA, sensitivity $96 \%$; specificity $98 \%)$; the average in farms was $51.8 \%(95 \% \mathrm{CI}$, 45.8 - 57.9), 16 were above the average with values between $58.3 \%$ and $84.0 \%$. The highest prevalences were found in the municipalities of Pueblo Nuevo (72.7\%), La Apartada (72.3\%), Monteria (62.9\%), Los Córdobas (59.9\%), Buenavista (59.7\%) and Ayapel $(51.9 \%)$. All visited farms were positive and therefore all buffalo-producing farms in the department of Córdoba are projected to be affected by BoHV-1, including 43,597 buffaloes.

For $\mathrm{bPI} 3 \mathrm{v}, \mathrm{AP}=71.7 \%$ and $\mathrm{TP}=73.6 \%$ (Indirect ELISA, sensitivity 97\%; specificity 99\%); the average in farms was $71.6 \%(95 \% \mathrm{CI}, 63.3$ 79.9), 18 farms were above the average with values between $80.0 \%$ and $100.0 \%$. The highest prevalences were found in the municipalities of Pueblo Nuevo (100\%), San Jose De Ure (94.8\%), Ayapel (88.3\%), Buenavista (82.5\%), Montelibano (79.0\%), La

Table 1 - Local and regional prevalence of BVDV, BoHV-1, bPI3v and BRSV, in farms and buffaloes in the department of Córdoba, Colombia.

\begin{tabular}{|c|c|c|c|c|c|c|c|c|c|c|c|c|c|c|}
\hline \multirow[t]{3}{*}{ Study Area } & \multicolumn{5}{|c|}{-----------------Prevalence in Farms------------- } & \multicolumn{9}{|c|}{-----------------------'Prevalence in Animals-------------------- } \\
\hline & \multicolumn{2}{|c|}{---BVDV--- } & \multirow{2}{*}{ BoHV-1 } & \multirow{2}{*}{$\mathrm{bPI} 3 \mathrm{v}$} & \multirow[t]{2}{*}{ BRSV } & \multicolumn{3}{|c|}{---BVDV--- } & \multicolumn{2}{|c|}{--BoHV-1-- } & \multicolumn{2}{|c|}{------bPI3v---- } & \multicolumn{2}{|c|}{----BRSV--- } \\
\hline & $\mathrm{n}$ & & & & & $\mathrm{n}$ & AP & TP & AP & $\mathrm{TP}$ & AP & $\mathrm{TP}$ & $\mathrm{AP}$ & $\mathrm{TP}$ \\
\hline Ayapel & 10 & 100 & 100 & 100 & 100 & 260 & 26.5 & 26.2 & 50.8 & 51.9 & 85.8 & 88.3 & 53.1 & 52.8 \\
\hline Buenavista & 5 & 80 & 100 & 100 & 100 & 86 & 27.9 & 27.8 & 58.1 & 59.7 & 80.2 & 82.5 & 65.1 & 65.7 \\
\hline Cienaga De Oro & 1 & 100 & 100 & 100 & 100 & 26 & 19.2 & 17.7 & 38.5 & 38.8 & 34.6 & 35.0 & 61.5 & 61.9 \\
\hline La Apartada & 1 & 100 & 100 & 100 & 100 & 10 & 10.0 & 7.0 & 70.0 & 72.3 & 70.0 & 71.9 & 90.0 & 92.5 \\
\hline Los Córdobas & 1 & 100 & 100 & 100 & 100 & 24 & 12.5 & 9.9 & 58.3 & 59.9 & 50.0 & 51.0 & 70.8 & 71.9 \\
\hline Montelibano & 8 & 100 & 100 & 100 & 100 & 181 & 23.2 & 22.3 & 44.8 & 45.5 & 76.8 & 79.0 & 66.3 & 67 \\
\hline Monteria & 3 & 100 & 100 & 100 & 100 & 72 & 15.3 & 13.1 & 61.1 & 62.9 & 47.2 & 48.1 & 62.5 & 62.9 \\
\hline Planeta Rica & 2 & 100 & 100 & 100 & 100 & 55 & 27.3 & 27.1 & 36.4 & 36.6 & 69.1 & 70.9 & 40.0 & 38.7 \\
\hline Pueblo Nuevo & 1 & 0.0 & 100 & 100 & 100 & 27 & 0.0 & 0.0 & 70.4 & 72.7 & 100.0 & 103.1 & 63.0 & 63.4 \\
\hline Sahagun & 1 & 100 & 100 & 100 & 100 & 21 & 9.5 & 6.4 & 52.4 & 53.6 & 38.1 & 38.6 & 52.4 & 52 \\
\hline San Bernardo & 1 & 100 & 100 & 100 & 100 & 25 & 16.0 & 14.0 & 52.0 & 53.2 & 48.0 & 49.0 & 88.0 & 90.3 \\
\hline San Jose De Ure & 1 & 100 & 100 & 100 & 100 & 25 & 20.0 & 18.6 & 40.0 & 40.4 & 92.0 & 94.8 & 40.0 & 38.7 \\
\hline Tierralta & 2 & 100 & 100 & 100 & 100 & 49 & 28.6 & 28.6 & 46.9 & 47.8 & 32.7 & 33.0 & 46.9 & 46.2 \\
\hline Córdoba & 37 & 94.6 & 100 & 100 & 100 & 861 & 22.6 & 21.7 & 50.4 & 51.5 & 71.7 & 73.6 & 58.8 & 58.9 \\
\hline
\end{tabular}

BVDV: bovine viral diarrhea virus; BoHV-1: bovine alphaherpesvírus 1; bPI3v: bovine parainfluenza virus; BRSV: bovine respiratory syncytial virus; AP: Apparent Prevalence; TP: True Prevalence. 
Apartada (71.9\%) and Planeta Rica (70.9\%). All farms were positive, 62,305 buffaloes are projected to be affected.

For BRSV, $\mathrm{AP}=58.8 \%$ and $\mathrm{TP}=58.9 \%$ (Competitive ELISA, sensitivity 97\%; specificity $96 \%$ ); the average in farms was $59.5 \%$ (95\% CI, 52.7 - 66.4), 15 farms were above the average with values between $68.2 \%$ and $95.0 \%$. The highest prevalences were found in the municipalities of La Apartada (92.5\%), San Bernardo del Viento (90.3\%), Los Córdobas (71.9\%), Montelíbano (67.0\%), Buenavista (65.7\%), Pueblo Nuevo (63.4\%), Montería (62.9\%) and Ciénaga de Oro (61.9\%). All farms were positive, 49,861 buffalo are projected to have been exposed to this virus.

Table 2 shows the univariate analysis. The four viral agents were associated with the age variable, where animals older than 24 months presented the highest risk of viral seropositivity. Regarding sex, females were more affected than males in terms of the four viral agents, but no difference was found for BVDV. Geographically, the most affected area was the
San Jorge River basin, with high significance for bPI3v ( $\mathrm{p}$-value $=0.000)$. Serological reactivity to several viruses was found among the buffaloes studied.

Multiple seropositivity or past coinfection of viral agents is evidenced in table 3 , where $23.3 \%$ of buffaloes were seropositive to a single virus, $31.8 \%$ were seropositive to two viruses, $29.4 \%$ were seropositive to three viruses, and $7.1 \%$ were seropositive to all four viruses. Only $8.4 \%$ of buffaloes were seronegative to all four viruses. 384 buffaloes were seropositive to BRSV and bPI3v; 349 buffaloes were seropositive to bPI3v and BoHV-1; 288 buffaloes were seropositive to BRSV and BoHV1; and 127 buffaloes were seropositive to BRSV and BVDV; 61 buffaloes presented seropositivity to the four viral agents, 50 located in the San Jorge River region and 11 in the Sinú River region.

Table 4 shows the final logistic regression models for each of the viral agents studied. The BVDV model only showed an association with the age variable, this same trend was repeated in the other models, showing a higher risk in buffaloes older than 24 months.

Table 2 - Univariate analysis between viral agents of bovine respiratory disease complex and age, sex, geographic region and coendemicity variables.

\begin{tabular}{|c|c|c|c|c|c|c|c|c|c|c|c|c|c|c|}
\hline \multirow[t]{2}{*}{ Variable } & \multirow[t]{2}{*}{ Category } & & \multicolumn{3}{|c|}{----------BVDV--------- } & \multicolumn{3}{|c|}{-------BoHV-1-------- } & \multicolumn{3}{|c|}{----------bPI3v---------- } & \multicolumn{3}{|c|}{----------BRSV--------- } \\
\hline & & $\mathrm{n}$ & Pos & $\%$ & p-value & Pos & $\%$ & p-value & Pos & $\%$ & p-value & Pos & $\%$ & p-value \\
\hline \multirow{4}{*}{ AGE } & 0 a $9 \mathrm{~m}$ & 229 & 27 & 11.7 & \multirow{4}{*}{0.000} & 80 & 34.9 & & 124 & 54.1 & \multirow{4}{*}{0.000} & 109 & 47.6 & \multirow{4}{*}{0.000} \\
\hline & 10 a $24 \mathrm{~m}$ & 129 & 30 & 23.2 & & 23 & 17.8 & 0.000 & 83 & 64.3 & & 65 & 50.3 & \\
\hline & $>24 \mathrm{~m}$ & 487 & 130 & 26.6 & & 329 & 67.5 & & 399 & 81.9 & & 327 & 67.1 & \\
\hline & Total & 845 & 187 & 22.1 & & 432 & 51.1 & & 606 & 71.7 & & 501 & 59.2 & \\
\hline \multirow{3}{*}{ SEX } & Females & 649 & 155 & 23.8 & \multirow{3}{*}{0.129} & 341 & 52.5 & \multirow{3}{*}{0.028} & 499 & 76.8 & \multirow{3}{*}{0.000} & 398 & 61.3 & \multirow{3}{*}{0.007} \\
\hline & Males & 212 & 40 & 18.8 & & 93 & 43.8 & & 118 & 55.6 & & 108 & 50.9 & \\
\hline & Total & 861 & 195 & 22.6 & & 434 & 50.4 & & 617 & 71.6 & & 506 & 58.7 & \\
\hline \multirow{3}{*}{ REGION } & SanJorge & 644 & 156 & 24.2 & \multirow{3}{*}{0.057} & 319 & 49.5 & \multirow{3}{*}{0.377} & 526 & 81.6 & \multirow{3}{*}{0.000} & 372 & 57.7 & \multirow{3}{*}{0.302} \\
\hline & Sinú & 217 & 39 & 17.9 & & 115 & 53 & & 91 & 41.9 & & 134 & 61.7 & \\
\hline & Total & 861 & 195 & 22.6 & & 434 & 50.4 & & 617 & 71.6 & & 506 & 58.7 & \\
\hline \multirow{3}{*}{ BVDV } & Pos & & & & & 102 & 52.3 & \multirow{3}{*}{0.546} & 149 & 76.4 & \multirow{3}{*}{0.094} & 127 & 65.1 & \multirow{3}{*}{0.040} \\
\hline & Neg & & & & & 332 & 49.8 & & 468 & 70.2 & & 379 & 56.9 & \\
\hline & Total & & & & & 434 & 50.4 & & 617 & 71.6 & & 506 & 58.7 & \\
\hline \multirow{3}{*}{ BoHV-1 } & Pos & 434 & 102 & 23.5 & \multirow{3}{*}{0.546} & & & & 349 & 80.4 & \multirow{3}{*}{0.000} & 288 & 66.3 & \multirow{3}{*}{0.000} \\
\hline & $\mathrm{Neg}$ & 427 & 93 & 21.7 & & & & & 268 & 62.7 & & 218 & 51.0 & \\
\hline & Total & 861 & 195 & 22.6 & & & & & 617 & 71.6 & & 506 & 58.7 & \\
\hline \multirow{3}{*}{ bPI3v } & Pos & 617 & 149 & 24.1 & \multirow{3}{*}{0.106} & 349 & 56.5 & 0000 & & & & 384 & 62.2 & $0 \Omega 01$ \\
\hline & Neg & 244 & 46 & 18.8 & & 85 & 34.8 & 0.000 & & & & 122 & 50.0 & 0.001 \\
\hline & Total & 861 & 195 & 22.6 & & 434 & 50.4 & & & & & 506 & 58.7 & \\
\hline & Pos & 506 & 127 & 25.1 & & 288 & 56.9 & & 384 & 75.8 & & & & \\
\hline BRSV & Neg & 355 & 68 & 19.1 & 0.040 & 146 & 41.1 & 0.000 & 233 & 65.6 & 0.001 & & & \\
\hline & Total & 861 & 195 & 22.6 & & 434 & 50.4 & & 617 & 71.6 & & & & \\
\hline
\end{tabular}

BVDV: bovine viral diarrhea virus; BoHV-1: bovine alphaherpesvírus 1; bPI3v: bovine parainfluenza virus; BRSV: bovine respiratory syncytial virus. 
Table 3 - Distribution of serum antibodies for multiple infections in buffaloes.

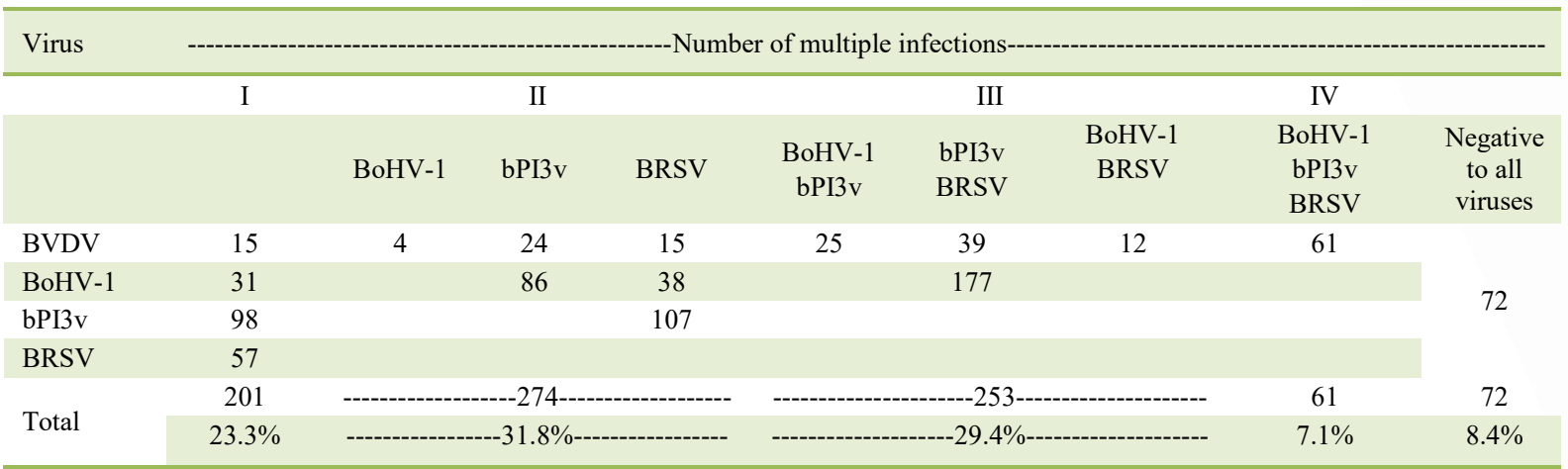

BVDV: bovine viral diarrhea virus; BoHV-1: bovine alphaherpesvírus 1; bPI3v: bovine parainfluenza virus; BRSV: bovine respiratory syncytial virus.

The sex variable was significant in the BoHV-1 and bPI3v models. In the BoHV-1 model, females showed 1.631 times lower risk of exposure $(\mathrm{OR}=0.613)$ compared to males. Conversely, in the bPI3v model, females presented 1.841 times higher risk of seropositivity compared to males.

The geographic region was associated with the bPI3v and BRSV models. In the bPI3v model, buffaloes from the San Jorge River region presented 7.131 times greater risk of seropositivity than animals from the Sinú River region. Conversely, in the BRSV model, buffaloes from the San Jorge River region presented 1.472 times lower risk of seropositivity $(\mathrm{OR}=0.679)$.

Multiple seropositivity was explained in all models by the magnitude of the risk of having seroreactivity to more than one viral agent. In the BVDV model, no multiple seropositivity was observed. In the BoHV-1 model, there was multiple seropositivity with $\mathrm{bPI} 3 \mathrm{v}$ and BRSV, the risk of having seropositivity to BoHV-1 and bPI3v was 1.844 times higher compared to animals that were only reactive to BoHV-1; Similarly, in the positivity with BRSV, the OR was 1.464 . In the bPI3v model, there was multiple seropositivity with BoHV-1 and BRSV, where the OR values were 2.312 and 1.456 , respectively. Finally, in the BRSV model, there was positivity with bPI3v and BoHV-1, where the OR values were 1.497 and 1.393 , respectively.

\section{DISCUSSION}

BRDC viruses have been reported in cattle in Córdoba and other departments of Colombia
(DORIA-RAMOS et al., 2020; MUÑOZ et al., 2020; VARGAS-NIÑO et al., 2018; BETANCUR et al., 2011; BETANCUR et al., 2010; BETANCUR et al., 2007; BETANCUR et al., 2006). However, there are scarce works on buffaloes at the national level (MOTTA et al., 2013). This is the first study that proves the circulation of the main BRDC viruses in the largest buffalo-producing department of Colombia.

The presence of antibodies in the buffaloes was inferred as evidence of viral circulation and past infection. Serological evidence was not influenced by the detection of post-vaccination antibodies because no farms had established vaccination plans against the four viral agents studied.

Producers in the department of Córdoba have believed that buffaloes are resistant to many infectious agents and vectors due to the high robustness and adaptability of these animals to lowland tropical conditions. However, the results showed high seroprevalence and suggest an important epidemiological role of buffaloes in the dissemination and transmission of these viruses; it can be stated that the viruses infected buffaloes and cattle in high levels, the infection can circulate between the two species at same time. Nevertheless, no risk was found due to the presence of cattle, and viral seropositivity in each farm was regardless of the presence or absence of cattle: BoHV-1 (p-value: 0.162), bPI3v (p-value: 0.289), BRSV, (p-value: 0.880), and BVDV (p-value: 0.972).

Buffaloes showed some evidence of unequal exposure to the viruses of interest, seroprevalence was higher in bPI3v $(71.7 \%)$ and BRSV (58.8\%), followed by BoHV-1 (50.4\%) and BVDV (22.6\%). A study on buffaloes in the 
Table 4 - Logistic regression models for BVDV, BoHV-1, bPI3v and BRSV seropositivity in buffaloes in the department of Córdoba, Colombia.

\begin{tabular}{|c|c|c|c|c|c|c|}
\hline Virus & Variable & Category & $\mathrm{P}$-value & O.R. & 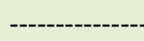 & [------ \\
\hline & & & & & Lower & Upper \\
\hline \multirow{3}{*}{ BVDV } & & 0 a $9 \mathrm{~m}$ & & & & \\
\hline & Age & 10 a $24 \mathrm{~m}$ & 0.005 & 2.267 & 1.278 & 4.020 \\
\hline & & $>24 \mathrm{~m}$ & 0.000 & 2.724 & 1.738 & 4.268 \\
\hline \multirow{6}{*}{ BoHV-1 } & & 0 a $9 \mathrm{~m}$ & & & & \\
\hline & Age & 10 a $24 \mathrm{~m}$ & 0.000 & 0.396 & 0.231 & 0.679 \\
\hline & & $>24 \mathrm{~m}$ & 0.000 & 3.837 & 2.620 & 5.620 \\
\hline & Sex & $\begin{array}{c}\text { Female } \\
\text { Male }\end{array}$ & 0.014 & 0.613 & 0.415 & 0.906 \\
\hline & $\mathrm{bPI} 3 \mathrm{v}$ & $\begin{array}{l}\text { Pos } \\
\text { Neg }\end{array}$ & 0.000 & 1.844 & 1.305 & 2.606 \\
\hline & BRSV & $\begin{array}{l}\text { Pos } \\
\text { Neg }\end{array}$ & 0.014 & 1.464 & 1.077 & 1.990 \\
\hline \multirow{8}{*}{ bPI3v } & & 0 a $9 \mathrm{~m}$ & & & & \\
\hline & Age & 10 a $24 \mathrm{~m}$ & 0.143 & 1.458 & 0.879 & 2.418 \\
\hline & & $>24 \mathrm{~m}$ & 0.000 & 2.141 & 1.389 & 3.300 \\
\hline & Sex & $\begin{array}{c}\text { Female } \\
\text { Male }\end{array}$ & 0.003 & 1.841 & 1.230 & 2.753 \\
\hline & REGION & $\begin{array}{c}\text { San Jorge } \\
\text { Sinú }\end{array}$ & 0.000 & 7.148 & 4.981 & 10.388 \\
\hline & BoHV-1 & $\begin{array}{l}\text { Pos } \\
\text { Neg }\end{array}$ & 0.000 & 2.312 & 1.574 & 3.398 \\
\hline & BRSV & Pos & 0037 & 1456 & 1021 & 2076 \\
\hline & DNS & Neg & 0.031 & 1.450 & 1.021 & $2.0 / 0$ \\
\hline \multirow{6}{*}{ BRSV } & & 0 a $9 \mathrm{~m}$ & & & & \\
\hline & Age & 10 a $24 \mathrm{~m}$ & 0.483 & 1.170 & 0.753 & 1.818 \\
\hline & & $>24 \mathrm{~m}$ & 0.000 & 1.913 & 1.355 & 2.701 \\
\hline & REGION & $\begin{array}{c}\text { San Jorge } \\
\text { Sinú }\end{array}$ & 0.035 & 0.679 & 0.474 & 0.974 \\
\hline & BoHV-1 & $\begin{array}{l}\text { Pos } \\
\text { Neg }\end{array}$ & 0.034 & 1.393 & 1.024 & 1.895 \\
\hline & bPI3v & $\begin{array}{l}\text { Pos } \\
\text { Neg }\end{array}$ & 0.024 & 1.497 & 1.054 & 2.127 \\
\hline
\end{tabular}

BVDV: bovine viral diarrhea virus; BoHV-1: bovine alphaherpesvírus 1; bPI3v: bovine parainfluenza virus; BRSV: bovine respiratory syncytial virus.

department of Caqueta did not find seropositivity for BVDV, but the seroprevalence for BoHV-1 was $80.3 \%$ (MOTTA et al., 2013). In cattle, higher exposure has also been proven for bPI3v $(67.6 \%)$ and BRSV (75.5\%) (MAHMOUD \& ALLAM, 2013). Differences were also observed among geographic regions, buffaloes from the San Jorge River basin presented the highest seroprevalence to BRDC viruses.

Producers were aware of the existence of respiratory and reproductive problems in their herds and the description in their farms showed high diversity in management and infrastructure.
The varied seropositivity among the four viruses and of each virus in the 37 farms could be a consequence of a combination between the diversity of management and sanitary control measures of each livestock producer and the particular infectivity capacities of each virus.

The 37 studied farms were positive for BoHV-1, bPI3v and BRSV, and only two were negative for BVDV. These results suggest a wide viral dissemination in the department of Córdoba, with evident circulation in all its municipalities and probably in most of the country's buffalo farms. 
The BVDV logistic regression model showed a particular independent behavior, not supporting seropositivity association with the other viruses. Animals older than 9 months were more affected, possibly due to the decrease in maternal antibodies and the increase in the time of exposure to the pathogen (ELLIS et al., 2001). On the other hand, although BVDV presented the lowest animal seroprevalence $(21.7 \%)$, its high prevalence at the farm level $(94.6 \%)$ generates a worrying health indicator due to its particular difficulty in control and eradication, and its important contribution to respiratory and reproductive problems (VARGAS et al., 2009). The difficulty in control and eradication is associated with the existence of persistently infected animals that while living are important reservoirs and transmitters of BVDV (VARGAS et al., 2009; VALDEZ et al., 2018). In Peru, a study in cattle determined a $50 \%$ seroprevalence to BVDV and a $2.2 \%$ prevalence of persistently infected animals in the population that was seronegative (VALDEZ et al., 2018).

BVDV and BoHV-1 are also associated with reproductive diseases (MCGILL \& SACCO, 2020), but the serology used in this study is not enough to differentiate the respiratory or reproductive form of the infection. Reproductive complex diseases are another topic that is little understood and needs to be studied in the buffalo populations of Colombia.

The other models presented multiple seropositivity association. Combined seropositivity may be a consequence of similar means of transmission (RAMÍREZ, 2016). It is possible for cattle to be seropositive at the same time with two different viruses, however, the most likely scenario is that the infections are sequential; several factors seem necessary but not sufficient to cause BRDC. Simultaneous or sequential infections with multiple pathogens, including viruses and bacteria, have been proposed (RIDPATH et al., 2020).

\section{CONCLUSION}

This is the first regional epidemiological study on the main BRDC viruses in the major buffaloproducing department in Colombia; although the high seroprevalence found is not equivalent to disease, it does present a worrisome epidemiological scenario for buffalo in Colombia and contradict the belief of buffalo's high resistance to infectious diseases. The high endemism of these viruses may be a consequence of the lack of control measures, being necessary to advance in preventive control and counteract the role of buffaloes as reservoirs of infection. It is necessary to quantify the clinical and productive impact of infection by these viruses, is required to expand the capacity for clinical and virological diagnosis of these viruses in buffaloes.

\section{ACKNOWLEDGMENTS}

The authors thank AGROSAVIA for the inclusion of this work in the research agenda; the Ministry of Agriculture and Rural Development (MADR) for funding; VECOL, especially Dr. Julio Tobon, for technical support; and the Colombian Association of Buffalo Breeders (ASOBUFALOS) for facilitating and supporting buffalo producers.

\section{DECLARATION OF CONFLICT OF INTEREST}

The authors declare to have no conflicts of interest.

\section{AUTHORS' CONTRIBUTIONS}

All authors contributed equally to the conception and preparation of the manuscript. All authors critically reviewed the manuscript and approved the final version.

\section{BIOETHICS AND BIOSSECURITY COMMITTEE APPROVAL}

This study did not go through the Animal Use Ethics Committee because it involved only routine clinical examinations.

\section{REFERENCES}

BETANCUR H. C. et al. Estudio seroepidemiológico del virus respiratorio sincitial bovino en el municipio de Montería, Colombia. Rev MVZ Córdoba, v.16, n.3, p.2778-2784, 2011. Available from: $<$ https://revistas.ces.edu.co/index.php/mvz/article/ view/3814>. Accessed: Apr. 26, 2020. doi: 10.21897/rmvz.278.

BETANCURH.C. etal.Estudioseroepidemiológicodel virusdeparainfluenza 3 en bovinos del municipio de Montería (Colombia) con trastornos reproductivos. $\operatorname{Rev}$ Mev Vet, v.1, n.20, p.63-70, 2010. Available from: $<$ https:// ciencia.lasalle.edu.co/cgi/viewcontent.cgi?article $=1037$ \& context $=\mathrm{mv}>$. Accessed: May, 05, 2020. doi: 10.19052/mv.583.

BETANCUR H. C. et al. Seroepidemiología de la diarrea viral bovina en Montería (Córdoba, Colombia). Analecta Vet, v.27, n.2, p.11-16, 2007. Available from: <http://sedici.unlp.edu.ar/ handle/10915/11204>. Accessed: Mar. 12, 2020.

BETANCUR H. C. et al. Seroepidemiología de la rinotraqueitis infecciosa bovina en el municipio de Montería, Colombia. Rev MVZ Córdoba, v.11, n.2, p.830-836, 2006. Available from: $<$ https://revistamvz.uniCórdoba.edu.co/article/view/447/515>. Accessed: Aug. 10, 2020. doi: 10.21897/rmvz.447.

CIRONE F. et al. Prevalence of pathogens related to bovine respiratory disease before and after transportation in beef steers: preliminary results. Animals (Basel), v.9, n.12, 1093, 2019. Available from: <https://pubmed.ncbi.nlm.nih.gov/31817737/>. Accessed: Aug. 12, 2020. doi: 10.3390/ani9121093. 
DOHOO I. R.; MARTIN S. W.; STRYHN H. Veterinary epidemiologic research. Charlotte, P.E.I: VER, Inc, 2009.

DORIA-RAMOS M. et al., Seroprevalencia de Agentes Virales del Complejo Respiratorio Bovino en Razas Criollas del Centro de Investigación Turipaná de AGROSAVIA. Rev Mex Cienc Pecu, v.11, n.3, p.771-782, 2020. Available from: <https:// cienciaspecuarias.inifap.gob.mx/index.php/Pecuarias/article/ view/5154>. Accessed: Oct 20, 2020. doi: 10.22319/rmcp. v11i3.5154.

ELLIS J. et al. Effect of maternal antibodies on induction and persistence of vaccine-induced immune responses against bovine viral diarrhea virus type II in young calves. J Am Vet Med Assoc, v.219, n.3, p.351-356, 2001. Available from: $<$ https://avmajournals. avma.org/doi/abs/10.2460/javma.2001.219.351>. Accessed: Jul. 03, 2020. doi: 10.2460/javma.2001.219.351.

GERSHWIN L. J. et al. Singles pathogen challenge with agents of the bovine respiratory disease complex. PLoS One, v.10, n.11, e0142479, 2015. Available from: <https://journals.plos.org/ plosone/article?id=10.1371/journal.pone.0142479>. $\quad$ Accessed: Sep. 27, 2020. doi: 10.1371/journal.pone.0142479.

GRISSETT G. P.; WHITE B. J. et al. Structured literature review of responses of cattle to viral and bacterial pathogens causing bovine respiratory disease complex. J Vet Intern Med, v.29, n.3, p.770780, 2015. Available from: <https://onlinelibrary.wiley.com/doi/ abs/10.1111/jvim.12597>. Accessed: Oct. 06 2020. doi: 10.1111/ jvim.12597.

ICA - Instituto Colombiano Agropecuario. Censo Pecuario año 2020. Censo Bovino en Colombia 2019. Available from: $<$ https:// www.ica.gov.co/areas/pecuaria/servicios/epidemiologia-veterinaria/ censos-2016/censo-2018.aspx>. Accessed: Jul. 27, 2020.

MAHMOUD M. A.; ALLAM A. M. Seroprevalence of bovine viral diarrhea Virus (BVDV), bovine herpes virus type 1 (BoHV-1), parainfluenza type 3 virus (PI-3V) and bovine respiratory syncytial virus (BRSV) among non vaccinated cattle. Global Veterinaria, v.10, n.3, p.348-353, 2013. Available from: <http://www.idosi. org/gv/gv10(3)13/18.pdf > . Accessed: Oct. 22, 2020. doi: 10.5829/ idosi.gv.2013.10.3.72119.

MCGILLJ. L.; SACCO R. E. The immunology of bovine respiratory disease: recent advancements. Vet Clin Food Anim, v.36, n.2, p.333-348, 2020. Available from: <https://www.sciencedirect.
com/science/article/abs/pii/S0749072020300190?via\%3Dihub>. Accessed: Oct. 18, 2020. doi:1016/j.cvfa.2020.03.002.

MOTTA G. J. L. et al. Seroprevalence of bovine viral diarrhea virus, bovine herpes virus 1 and 4 in cattle and buffaloes in the Department of Caquetá, Colombia. Rev Salud Anim, v.5, n.3, p.174-181, 2013. Available from: $<\mathrm{http}: / /$ scielo.sld.cu/scielo.php?script $=$ sci arttext\&pid=S0253-570X2013000300005 $>$. Accessed: Oct. 182020.

MUÑOZ, M. A. L. et al. Prevalence of bovine infectious rhinotracheitis virus in Caquetá department, Colombian Amazon. Rev Med Vet Zoot, v.67, n.1, p.9-16, 2020. Available from: <https://revistas.unal. edu.co/index.php/remevez/article/view/87675>. Accessed: Oct. 11, 2020. doi: 10.15446/rfmvz.v67n1.87675.

RAMÍREZ V. N. F. et al. Seroprevalence and risk factors of several bovine viral diseases in dairy farms of San Pedro de los Milagros, Antioquia, Colombia. Rev. CES Med. Vet. y Zootec, v.11, n.1, p.15-25, 2016. Available from: <https://revistas.ces.edu.co/index.php/mvz/article/ view/3814>. Accessed: Aug. 15, 2020. doi: 10.21615/ces mvz.11.1.2.

RIDPATH J. F. et al. Sequential exposure to bovine viral diarrhea virus and bovine coronavirus results in increased respiratory disease lesions: clinical, immunologic, pathologic, and immunohistochemical findings. Journal of Veterinary Diagnostic Investigation. v.32, n.4, p.513-526, 2020. Available from: $<\mathrm{https://}$ journals.sagepub.com/doi/full/10.1177/1040638720918561>. Accessed: Sep. 15, 2020. doi: 10.1177/1040638720918561.

VALDEZ G. E. et al. Identificación de bovinos persistentemente infectados y genotipo del virus de la diarrea viral en bovinos de Anta, Cusco, Perú. Rev Inv Vet Perú, v.29, n.4, p.1527-1537, 2018. Available from: <https://revistasinvestigacion.unmsm.edu. pe/index.php/veterinaria/article/view/15192/13326>. Accessed: Sep. 18, 2020. doi: 10.15381/rivep.v29i4.15192.

VARGAS D. S. et al. Perspectivas para el control del virus de la diarrea viral bovina (BVDV). Rev Colomb Cienc Pecu, v.22, n.4, p.677-688, 2009. Available from: <http://www.scielo.org.co/pdf/ rccp/v22n4/v22n4a11.pdf>. Accessed: Sep. 18, 2020.

VARGAS-NIÑO A. et al. Serological status of IBR, BVD, leucosis, leptospira and neospora caninum in bovine females of the department of Santander, Colombia. Revista MVZ Córdoba, v.23, n.2, p.6671-6680, 2018. Available from: <https://revistamvz. uniCórdoba.edu.co/article/view/1341/pdf>. Accessed: Sep. 18, 2020. doi: $10.21897 / \mathrm{rmvz} .1341$ 